\title{
Developing an Interdisciplinary Organic and Sustainable Agriculture Curriculum at the University of Florida
}

\author{
James J. Ferguson ${ }^{1}$, Elizabeth Lamb ${ }^{2}$, and Mickie Swisher ${ }^{3}$
}

ADDITIONAL INDEX WORDS. SARE, extension, organic growers, undergraduate

SUMMARY. With funding to increase support for organic farming research at land grant universities, organic growers have collaborated with faculty and administrators to develop an undergraduate, interdisciplinary minor at the University of Florida. Required introductory courses focus on general concepts of organic and sustainable farming, alternative cropping systems, production programs, handling, and marketing issues. An advanced horticulture course requires intensive examination of certification procedures, farm plans, soil fertility, and crop management, all of which are integrated into a required field project. Extension faculty have also fostered development of this new curriculum by coordinating regional workshops and field days in collaboration with organic growers and by developing educational materials on organic certification and related issues.

$\mathrm{O}$ ver the past 20 years, extension faculty at the University of Florida (UF) have consulted with local organic growers on production practices, written extension publications on organic farming and gardening, and co-sponsored organic farming workshops with local organic groups. However, it was not until Florida Certified Organic Growers and Consumers (FOGC) implemented a Southern Sustainable Agriculture Research and Education (SARE) farmer/rancher grant on "Developing a Model to Increase Support for Organic Farming Research at Land Grant Institutions" that an organic and sustainable crop production curriculum was developed at UF. The initial objective of this grant was to assemble a "multidisciplinary team of researchers and extension personnel ... to create a model for the development of research priorities and an organic research and education center" (Florida Organic Growers and Consumers, 2003). Through a series of meetings with FOGC, UF research deans, department chairs, and faculty with an interest in sustainable and organic agriculture, a Center for Organic Agriculture (COA) was established at UF and 10 acres (4.0 ha) of land certified in 2001 at the UF Plant

${ }^{1}$ Horticultural Sciences Department, University of Florida, Gainesville.

${ }^{2}$ Horticultural Sciences Department, University of Florida, Indian River Research and Education Center, Ft. Pierce.

${ }^{3}$ Family, Youth, and Community Services Department, University of Florida, Gainesville.
Science Research and Education Unit near Citra, Fla. This collaboration also paved the way for the development of a sustainable and organic curriculum in this area, which is reviewed here.

The above activities, along with increased student interest, prompted establishment of an undergraduate, interdisciplinary minor in organic and sustainable crop production in 2005 within the Horticultural Sciences Department. An undergraduate curriculum committee composed of faculty from agronomy, food and resource economics, entomology and nematology, family, youth and community services, horticultural sciences, plant pathology, soil and water science, and wildlife ecology and conservation worked together for over 1 year to develop this undergraduate minor and also to propose an undergraduate major, which is being considered (Lamb et al., 2005). Requirements for the undergraduate minor include two required introductory three-credit courses: Organic and Sustainable Crop Production (HOS 3281C), offered by the Horticultural Sciences Department, and Alternative Cropping Systems (AGR4215), offered through the Agronomy Department.

The introductory agronomy course was first taught in the Fall 2003 semester, with enrollment ranging from 10 to 15 students, both domestic and international, over 3 years; the introductory horticultural sciences course is scheduled for the Fall 2006 semester, with course descriptions for 
both courses to be published in the 2006 UF undergraduate catalog. The horticulture course presents the basic concepts and techniques of organic and sustainable crop production, including soil and water management, pest management, harvesting, and marketing (Table 1). The agronomy course examines the design and implementation of alternative cropping systems, "focusing on issues of sustainability against a backdrop of trends occurring in conventional agriculture" (Table 2). An additional nine credits, with three credits selected from each of three areas (crop production, pest management, and resource management areas), are also required (Table 3 ). The introductory courses are a prerequisite for an advanced organic and sustainable crop production course (HOS 4218C) not yet scheduled. Lecture topics for this advanced course include more in-depth, hands-on experiences with the organic certification process and comparisons of farm plans for organic, sustainable, and conventional systems. In this course, student teams develop a demonstration field project and also create a production and certification plan. The two introductory courses and the advanced course in organic and sustainable crop production stress the development of critical thinking skills, research-based production practices, and application of concepts to either field demonstration plots or case studies. The basic text for both the introductory and the advanced horticulture courses in organic and sustainable crop production is Sustainable Horticulture: Today and Tomorrow (Poincelot, 2003). Additional materials include The New Organic Grower (Coleman, 1989), Sustainable Vegetable Production from Start-Up to Market (Grubinger, 1999), and The Complete Book of Composting (Rodale, 1971). An additional reference for the advanced horticulture course in organic and sustainable crop production is Steel in the Field: A Farmer's Guide to Weed Management Tools (Bowman, 2002). Alternative Agriculture (National Research Council, 1989) is the required text for the Alternative Cropping Systems course with Agroecology: The Science of Sustainable Agriculture (Altieri, 1995) and other websites and SARE publications suggested.
Table 1. General lecture topics for the Horticultural Sciences Department, University of Florida, introductory Organic and Sustainable Crop Production course (HOS 3281C). ${ }^{\mathrm{z}}$

Definitions of organic and sustainable agriculture, agroecology, and other farming systems

History and philosophy of the organic farming movement

Comparisons with conventional farming systems

National organic standards and related standards

Organic certification and the transition from conventional to organic production

Soil fertility: compost, manures, cover crops, carbon : nitrogen ratios

Water management: National Organic Program water quality standards

Weed management

Biological control

Disease and pest management: National Organic Program (NOP) standards, mechanisms of resistance, cultural practices, approved disease and pest management products

Greenhouse production

Postharvest handling and transportation: NOP standards

Research on health and nutritional benefits

Markets and marketing: labeling; good organic retail practices; market share, and price differentials

${ }^{2}$ Three credits.

Table 2. General topics for the University of Florida, Agronomy Department, course in Alternative Cropping Systems (AGR 4215). ${ }^{\mathrm{z}}$

Definitions, current trends, and history: alternative and sustainable agriculture; the Green Revolution; family farms, corporate farms and changes in rural communities

Design of alternative cropping systems and technologies: case studies in organic production of large-scale food and fiber crops

Alternative production systems: polyculture, genetically modified organisms, cover cropping, crop rotation, mulching and minimum tillage, agroforestry, vermiculture, pasture management

Ecological pest and disease management

Economic evaluation of alternative cropping systems: production costs and impact of government programs

Case studies of production systems in the U.S. and other countries

${ }^{2}$ Three credits.

Table 3. Elective courses for the University of Florida, Horticultural Sciences Department, minor in organic and sustainable crop production. ${ }^{\mathrm{z}}$

\begin{tabular}{|c|c|c|}
\hline Crop production & Pest management & Resource management \\
\hline $\begin{array}{l}\text { Sustainable agricultural } \\
\text { systems analysis }\end{array}$ & Insect field biology & $\begin{array}{l}\text { Agricultural and } \\
\text { environmental quality }\end{array}$ \\
\hline Plants, health, and spirituality & Control of plant diseases & Agricultural ecology \\
\hline $\begin{array}{l}\text { Advanced organic and } \\
\text { sustainable crop production }\end{array}$ & $\begin{array}{l}\text { Principles of weed } \\
\text { management }\end{array}$ & $\begin{array}{l}\text { Agriculture water } \\
\text { management }\end{array}$ \\
\hline Plant propagation & $\begin{array}{l}\text { Foundations of pest } \\
\text { management }\end{array}$ & Soil, water, and land use \\
\hline World herbs and vegetables & $\begin{array}{l}\text { Field techniques in } \\
\text { integrated pest } \\
\text { management }\end{array}$ & $\begin{array}{l}\text { Soil and water } \\
\text { conservation }\end{array}$ \\
\hline
\end{tabular}

${ }^{\mathrm{z}} \mathrm{A}$ minimum of three credits from each of the following areas is required. Each of the above courses is three credits. 
Other related department and administrative activities have preceded the development of this curriculum. Vegetable production courses within the Horticultural Sciences Department have included topics related to the above courses and UF has long provided separate organic and conventional garden plots for students, faculty, and staff. Undergraduate students have also worked with local organic grower groups like FOGC on a grant-funded Neighborhood Nutrition Network Project and have volunteered with local organic growers. The UF administration, the Horticultural Sciences Department and other departments have also provided specific program support for sustainable and organic agriculture. A recently hired faculty member in the Horticultural Sciences Department with a $65 \%$ research and $35 \%$ extension appointment in sustainable and organic vegetable production will cooperate with established faculty working in weed management in organic vegetables and organic fruit crops production. Faculty in the Agronomy Department also have teaching and research responsibilities for sustainable agriculture systems. An online Organic Production and Marketing Newsletter (UF Horticultural Sciences Department, 2005) has been published 17 times since 1999 with topics on generic organic farming issues, commodity reports, and summaries of current American Society for Horticultural Science workshops and abstracts on organic farming. The UF College of Agriculture and Natural Resources manages an organic farming listserve with 143 faculty and grower members for announcements of organic farming events and online discussion of organic farming topics.

The U.S. Department of Agriculture's National Agricultural Library in 2003 listed approximately 23 universities and colleges in the U.S. offering undergraduate and graduate degree programs, separate courses, and internships on organic and sustainable agriculture (National Agriculture Library, 2003). However, the UF organic and sustainable agriculture curriculum is a new, developing program, especially compared with programs and internships available at other land grant and public institutions in the U.S. and abroad. For example, the Center for Agroecology and Sustainable Food Systems at the University of California, Santa Cruz, has developed a course description and detailed course outline on "Exploring Sustainability in Agriculture" that includes lectures, laboratories, and a 600-page resource manual for instructors (University of California, Santa Cruz, 2005).

The University of Kentucky (Lexington) began an innovative course in 1999 in which students discussed organic farming concepts and case studies with selected farmers around the country by teleconferences during class time (Bhavsar, 2002). At McGill University (Montreal), faculty have developed a conceptual framework and course outline for sustainable agriculture education in Canada (Hill and Macra, 2005). The University of Turin (Italy) offered a Summer 2004 course, "The Human Context in Organic Farming," that provided “...historical, philosophical, socioeconomic, health and nutritional aspects of organic farming" including lectures, farm visits, and marketing concepts (Fenocchio, 2005). As student interest grows and organic market share increases, UF will provide opportunities for students in sustainable and organic agriculture through apprenticeships for farmers and market gardeners; campus-based community supported agriculture; and field-oriented organic agriculture undergraduate and graduate programs modeled on those successful at other land grant institutions (Sullivan, 2005).

\section{Literature cited}

Altieri, M.A. 1995. Agroecology: The science of sustainable agriculture. Westview Press, Boulder, Colo.

Bhavasar, V.M. 2002. Certified organic farming principles and practices: A course linking farmers and university students. 17 Oct. 2005. <http://72.14.207.104/ search?q=cache:PjeNBCecqDcJ:www. jnrlse.org/pdf/2002/E01-14.pdf+Victo ria + Mundy+Bhavsar\&hl=en $>$.

Bowman, G. (ed.). 2002. Steel in the field: A farmer's guide to weed management tools. Sustainable Agr. Network, Beltsville, Md.
Coleman, E. 1989. The new organic grower. Chelsea Green Publ., White River Junction, Vt.

Fenocchio, G. 2005. Human context in organic farming. 29 Nov. 2005. <http:// www.divapra.unito.it/en/education/human.htm>.

Florida Certified Organic Growers and Consumers. 2003. Developing a model to increase support for organic farming research at land grant institutions. 14 Oct. 2005. <http://www.sare.org/reporting/ report_viewer.asp?pn=FS01-138>.

Grubinger, V. 1999. Sustainable vegetable production from start-up to market. Natural Resource Agr. Eng. Serv., Cornell Univ. Coop. Ext. Ser., Ithaca, N.Y.

Hill, S. and R. Macrae. 2005. Developing sustainable agriculture education in Canada. 28 Nov. 2005. <http://www.eap. mcgill.ca/Publications/EAP33.htm>.

Lamb, E., R. Darnell, C. Hutchinson, E. Simonne, and M. Webb. 2005. Integrating organic and sustainable agriculture into a horticultural science curriculum. Acta Hort. 672:197-203.

National Agricultural Library. 2003. Educational and training opportunities in sustainable agriculture. 17 Oct. 2005. <http://www.nal.usda.gov/afsic/AFSIC_ pubs/edtr.htm\#United\%20states $>$.

National Research Council. 1991. Sustainable agriculture research and education in the field: A proceedings. Natl. Acad. Press, Washington, D.C.

Poincelot, R.P. 2003. Sustainable horticulture: Today and tomorrow. Prentice Hall, Upper Saddle River, N.J.

Rodale, J. 1971. The complete book of composting. Rodale Press, Emmaus, Pa.

Sullivan, D. 2004. Student farms: Michigan State University, East Lansing. 29 Nov. 2005. <http://www.newfarm.org/features $/ 0804 / \mathrm{msu} /$ index.shtml $>$.

University of California, Santa Cruz. 2005. Exploring sustainability in agriculture. 28 Nov. 2005. <http://zzyx.ucsc.edu/casfs/ instruction/esa/description.html>.

University of Florida, Horticultural Sciences Department. 2005. Organic farming and production newsletter. 15 Oct. 2005. <http://www.hos.ufl.edu/jjfnweb/organicnl/organic.htm>. 